UDC 911.375:314.116(4-11)

Lyudmyla Mykolaivna Niemets,

Doctor of Sciences (Geography), Professor,

Head of the Department of Human Geography and Regional Studies,

V. N.Karazin Kharkiv National University,

Svobody sq., 4, Kharkiv, 61022, Ukraine,

e-mail: soc-econom-region@karazin.ua, https://orcid.org/0000-0001-9943-384X;

Olga Sergiivna Suptelo,

$\mathrm{PhD}$ student, Department of Human Geography and Regional Studies,

V. N.Karazin Kharkiv National University,

e-mail: syptelo@gmail.com, https://orcid.org/0000-0003-2901-8565;

Sergii Oleksandrovich Zavetnyi,

Doctor of Science (Philosophy), Professor,

Department of theoretical and practical philosophy, V. N.Karazin Kharkiv National University, e-mail: kntusgunesco96@gmail.com,

Volodymir Ivanovich Redin,

$\mathrm{PhD}$ (Geography), Associate Professor, Department of Human Geography and Regional Studies, e- mail: v.redin@gmail.com, https://orcid.org/0000-0002-1580-7662;

Anatoliy Mikhailovich Baynazarov,

$\mathrm{PhD}$ (Geography), Associate Professor,

Department of Physical Geography and Cartography, V. N. Karazin Kharkiv National University, e-mail: baynazarov@ukr.net

\title{
DYNAMICS OF THE POPULATION NUMBER IN GLOBAL CITIES OF THE EAST EUROPEAN REGION*
}

Л.М. Нємець, О.С. Суптело, С.О. Завєтний, В.І. Рєдін, А.М. Байназаров. ДИНАМІКА ЧИСЕЛЬНОСТІ НАСЕЛЕННЯ ГЛОБАЛЬНИХ МІСТ СХІДНО-СВРОПЕЙСЬКОГО РЕГІОНУ. В статті здійснено аналіз показників динаміки чисельності населення глобальних міст Східно-Свропейського регіону та їх частки в населенні відповідних країн за період 2000-2018 роки. Обгрунтовано важливість проведення досліджень демографічних особливостей розвитку глобальних міст, зокрема в регіональному розрізі, адже глобальні міста є наразі провідними иентрами економічного, фінансового, політичного, культурного, сочіального, культурного розвитку.

Виявлені особливості та основні тенденції динаміки чисельності населення та частки населення в відповідних країнах досліджуваних глобальних міст Східно-Європейського регіону за період 2000-2018 роки. Здійснено групування глобальних міст регіону за період дослідження за показниками динаміки чисельності населення з 2000 по 2018 роки, частки населення досліджуваних міст в населенні відповідних країн. Проведено кластерний аналіз глобальних міст регіону за вище перечисленими показниками, за результатом якого виділено групи міст для яких зі збереженням існуючих темпів демографічного розвитку характерним буде: збереження статусу глобальних - Москва, Санкт-Петербург, Київ; втрата статусу глобальних міст - Будапешт, Прага, Софія, Вроилава; міста для яких необхідно впровадження заходів для збереження статусу глобальних - Мінськ, Бухарест, Варшава.

Ключові слова: глобальні міста, Східно-европейський регіон, частка населення міста в населенні крайни, рівень урбанізації, ріст (скорочення) населення.

Л.М. Немец, О.С. Суптело, С.А. Заветный, В.И. Редин, А.М. Байназаров. ДИНАМИКА ЧИСЛЕННОСТІ НАСЕЛЕНИЯ ГЛОБАЛЬНЫХ ГОРОДОВ ВОСТОЧНО-ЕВРОПЕЙСКОГО РЕГИОНА. В статье проведен анализ показателей динамики численности населения глобальных городов Восточно-Европейского региона и их доли в населении соответствующих стран за период 2000-2018 годы. Обоснованно важность проведения исследований демографических особенностей развития глобальных городов, в частности в региональном разрезе, ведь глобальные города являются сейчас ведущиими иентрами экономического, финансового, политического, культурного, сочиального, культурного развития.

Выявлены особенности и основные тенденции динамики численности населения и доли населения в соответствующих странах изучаемых глобальных городов Восточно-Европейского региона за период 2000-2018 годы. Осуществлено группировки глобальных городов региона за период исследования по показателям динамики численности населения с 2000 по 2018 годы, доли населения исследуемых городов в населении соответствующии стран. Проведен кластерный анализ глобальных городов региона по выше перечисленными показателями, по результатам которого выделено группы городов для которых с сохранением существующих темпов демографического развития характерным будет: сохранение статуса глобальных Москва, Санкт-Петербург, Киев; потеря статуса глобальных городов - Будапешт, Прага, София, Вроилава; города для которых необходимо внедрение мероприятий для сохранения статуса глобальных - Минск, Бухарест, Варшава.

Ключевые слова: глобальные города, Восточно-европейский регион, доля населения города в населении страны, уровень урбанизащии, рост (сокращение) населения.

Formulation of the problem. The growth of cities and their population number determines the urgent need to study urban demographic processes. According to the UN [12], in 2007, urban population of the world exceeded rural population and was
$54 \%$, respectively, while this figure continues to grow. In most countries of the world where there global cities, they are the most developed cities of the country, in the vast majority of them - these are the capital cities. These features are typical for the (C) Niemets L. M., Suptelo O. S., Zavetnyi S. O., Redin V. I., Baynazarov A. M. 
countries of the studied region -East Europe, of the 11 global cities in the region, 9 are capitals.

There is currently no comprehensive analysis of the demographic processes of global cities. Most studies of global cities are limited to building their hierarchical classification and studying global networks. Therefore, an increase in the proportion of urban population, in particular the population of global cities, which are currently the leading centers of economic, financial, political, cultural and social development, makes the study of the demographic processes of these territories more urgent.

Analysis of previous research. The overwhelming majority of studies and their corresponding publications devoted to global cities on the basis of them, have a theoretical component and are the basis for the formation of global cities concept. The concept of "global cities" was first used by $\mathrm{O}$. Spengler in 1918 [6]. According to O. Spengler, this term meant a large-scale resettlement formed when several smaller populations of agglomerations united.

S. Sassen gave the most common definition of the "global city" in his work "Global City: New York, London, Tokyo" [3]. In his publications, S. Sassin emphasizes mainly the economic and financial role of the global city in the country and the world, stressing the importance of the tertiary sector of the economy in these cities [14].

Since the mid 1990s, the study of global cities has also been conducted by P. Taylor [15] and the group GlobalizationandWorldCities (GaWC) [19]. In the study of global cities, these authors even use a large list of criteria but they focus on corporate and other financial services provided in global cities, as well as on employment in the services and urban residents' life quality $[15,16]$.

V. Glazychev [1] in the book "Urbanistics" (2008) draws attention to the role of global cities in transforming the national economy and its inextricable link with the global economy. The work of I. Voronin "Formation of Global Cities as the Result of the Influence of the Processes of Globalization and Informatization on the Resettlement System" [7] is another study of global cities in terms of the economic approach in which the author has focused his attention on the functions performed by global cities and their effects on economic sphere.

M. Sluck and O. Matveev also emphasize the vital role of global cities in the development of the country and their fundamental potential and resources in a number of publications $[2,5]$. O. Matveev considers global cities as the main factors of changing socio-cultural space [4]. Instead, M. Sluck in the book "Geodemographic phenomena of global cities" provides an exhaustive analytical description of global cities of the world but does not consider them in a regional context [2].
Problems of further research. Despite a large number of publications, most authors emphasize the importance of the economic development component of world cities in their research. The demographic situation is regarded only as one of the factors in the development of global cities. It is this fact that determines the relevance of the demographic situation of global cities study, especially in the regional context.

The purpose of this study is to analyze the dynamics of the population of the global cities in the Eastern European region. To achieve the goal, the following tasks were set: to analyze the population dynamics of the global cities in the Eastern European region; to identify the impact of global cities on the development of the countries concerned by analyzing the share of population in the countries; to group the global cities of the region under study in terms of the population dynamics and the share in the population of the respective countries. The object of research is global cities, the subject - the peculiarities of the population dynamics of the global cities in the East European region.

Research methods. The study of the population dynamics of the global cities in the East European region involves the use of a system of methods that allows assessing demographic processes in them and determines their impact on the development of the countries concerned. In this study, general and special-scientific methods were used. In particular, as a result of the custody of the anzilla, a grouping of the global cities of the East European region was carried out based on the dynamics of the population and their share in the population of the countries concerned during the period of investigation.

Presentation of the main research material. The current political and economic situation in Europe and the fact that more than $30 \%$ of the population lives in this macro-region - increases interest in studying the countries of the Eastern European region and, in particular, the cities. According to the classification of the United Nations macroregions, the following countries are included in the Eastern European region: Belarus, Bulgaria, Moldova, Poland, Moldova, Russia, Romania, Slovakia, Hungary, Ukraine, the Czech Republic. These countries are buffer between the developed countries of Europe and the Asian countries. They have a similar history of formation, and the population peculiarities have a number of similar features.

In 2016 in the investigated region "Globalization and World Cities" (GaWC) identified 11 global [25] cities. A macroregion in each country, except for Moldova, is a global city, among these global cities all except St. Petersburg and Wroclaw are metropolitan cities.

Each of the studied countries of the region has a high level of urbanization - more than $53.2 \%$ (Slo- 
vakia) (Fig. 1). This indicator is quite arbitrary, because in each individual country, the status of the city has settlements with different characteristics. The most common criterion for the city allocation, besides the type of employment, is the population of the settlement. In this region, this indicator ranges from 1.000 to 12.000 , although in fact, in each country in the region, there are cities with population below the statutory minimum for obtaining such status. Conditional levels of urbanization can be divid-
- low level of urbanization - less than $20 \%$;

- average urbanization rate - from $20 \%$ to $50 \%$;

- high level of urbanization - from 50\% to $72 \%$;

- very high level of urbanization - more than $72 \%$.

Therefore, all countries in the region under study have high (Slovakia, Romania, Poland, Ukraine) and very high (Hungary, Czech Republic, Russia, Bulgaria, Belarus) level of urbanization.

Of the 11 studied cities, as of January 1, 2018, ed into:

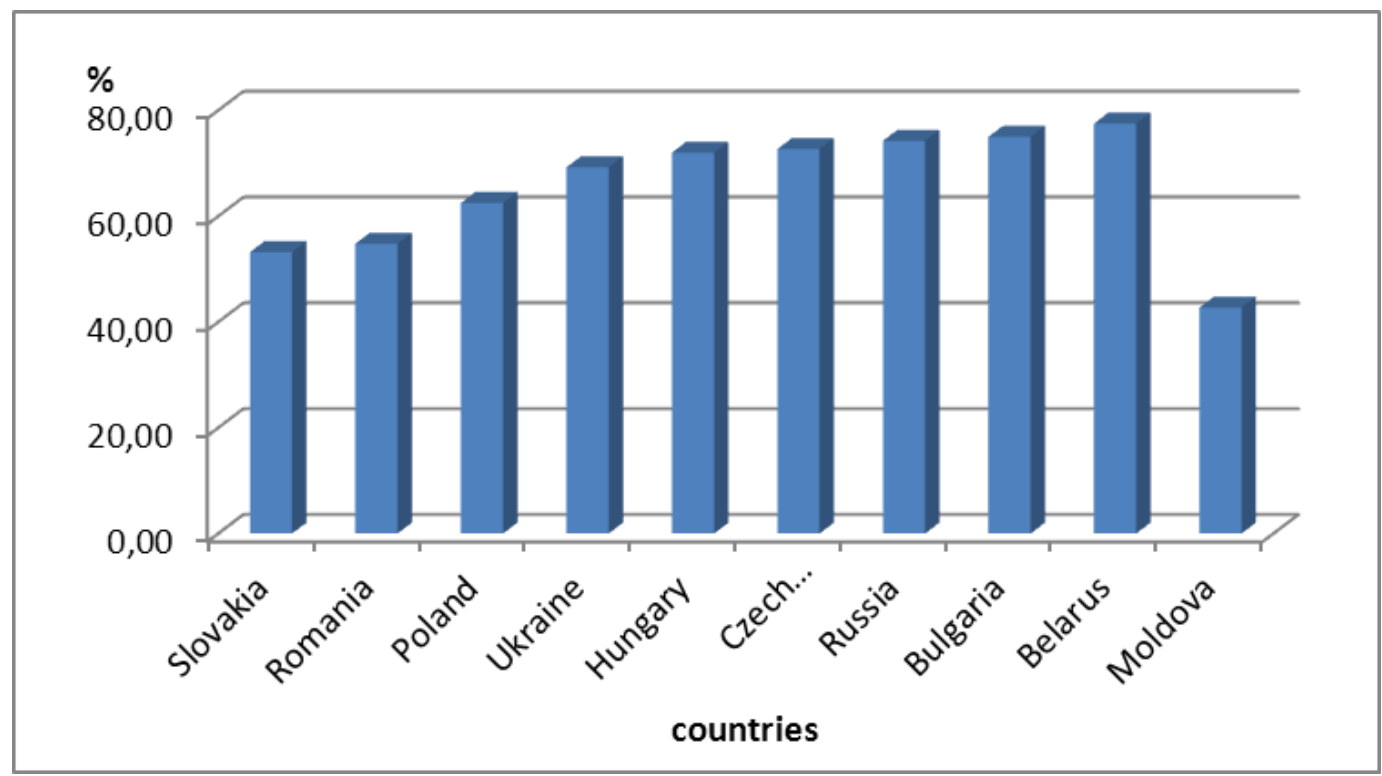

Fig. 1. Urbanization level in East European region

as of 01.01.2018, (built by the author according to [8-13; 17-18; 20-24])

the largest population index was recorded in the city of Moscow (Russia) - more than 12506 thousand people, respectively, the least -416.5 thousand people in Bratislava (Slovakia).

In general, the global cities of the East European region by population as of 01.01.2018 can be divided into three groups (Fig. 2):

- cities with a population of up to 1 million people - Bratislava (Slovakia), Wroclaw (Poland);

- cities with a population of 1 million to 5 million people - Sofia (Bulgaria), Prague (Czech Republic), Budapest (Hungary), Warsaw (Poland), Minsk (Belarus), Bucharest (Romania), Kiev (Ukraine);

- cities with a population of more than 5 million people - St. Petersburg (Russia), Moscow (Russia).

For three cities under study Bratislava, Budapest, Wroclaw the dynamics of the population declines, as opposed to the rest of the studied global cities. During the study, the population of the city of Bratislava dropped by 20.88 thousand, which is $4.67 \%$, respectively. This situation is caused by a number of factors, in particular the country's traditional natural growth rates, the proximity of the city to the state border with Austria and the city of Vien- na (the distance between the capitals is about 55 $\mathrm{km})$. The accession of the country to the EU in 2004 is important as it has become the main stimulant of population migration and has affected the population decline, mainly due to migration (Fig. 1, 2).

A similar situation is typical for the city of $\mathrm{Bu}-$ dapest; during the study period the city population declined by more than 38 thousand people, which corresponds to $-2.16 \%$, respectively (Fig. 2). After the accession of Hungary to the EU in 2004, the city's population increased by about $4 \%$, although it did not equal the level of the beginning of the studied period.

Trends in population decline are also recorded for the city of Wroclaw. During the research period, the population declined by 9.42 thousand people, or $-1.47 \%$, respectively (Fig. 3). This situation is due in part to the above-mentioned fact of the country's accession to the EU, as well as the situation of the city of Wroclaw in the country. Since Wroclaw is located in the Lower Silesian province of Poland bordering Germany and the Czech Republic, after the country's accession to the EU, a large number of the province's population migrated to these countries, which generally has led to a reduction in the population of the city of Wroclaw. 


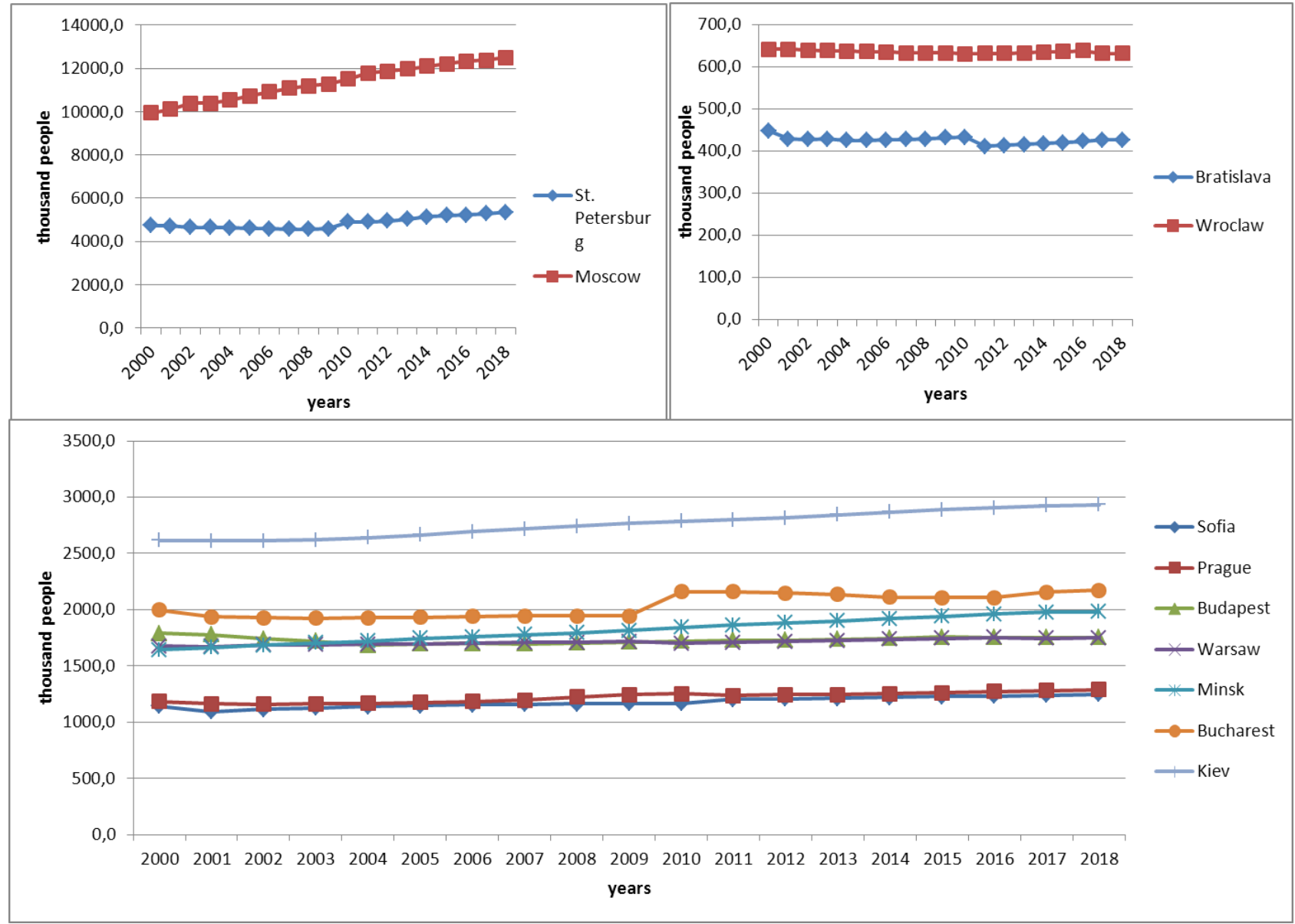

Fig. 2. Dynamics of the global population for the content of Eastern European region for the period 2000-2018 (built by the author according to [8-10; 13; 17-18; 20-24])

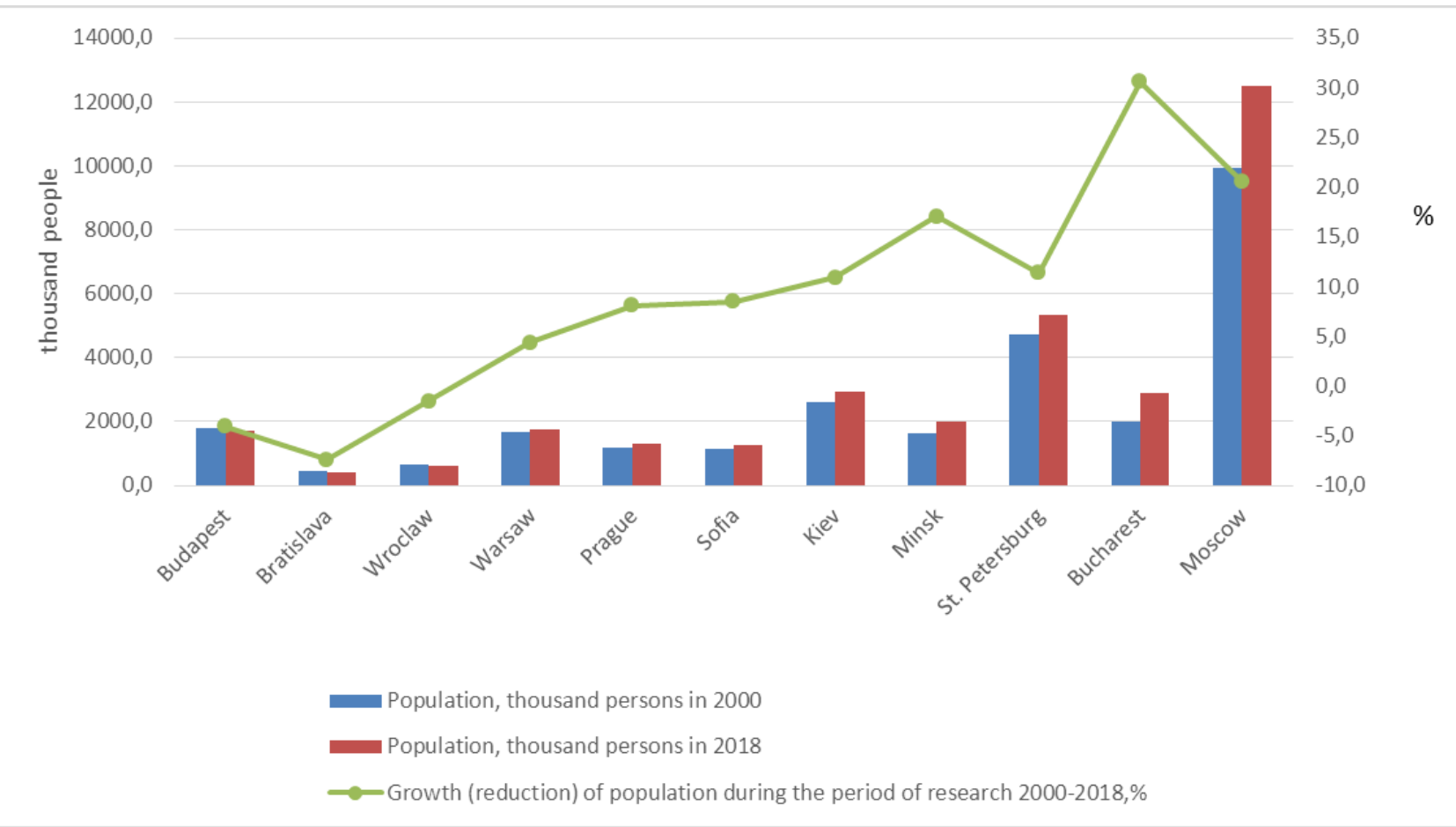

Fig. 3. Growth (reduction) of global cities' population in Eastern European region for the period 2000-2018 (constructed by the author according to [8-10; 13; 17-18; 20-24])

The rest of the studied cities characterized by a namely: Moscow $-25.91 \%$, Minsk $-20.55 \%$, St. gradual increase in population over the period 2000- Petersburg $-12.86 \%, \mathrm{Kiev}-12.21 \%$. An increase in 2018 years, e.g. the cities of the former USSR, the population during the study period was over 
$10 \%$, which is the reason for the change in socioeconomic and political situation in the countries. These cities "drag out" a fairly significant proportion of the population of the countries concerned, as the most socio-economically migratory attractiveness for the population.

The population of such cities as Sofia (9.27\%), Bucharest $(8.83 \%)$, Prague $(8.78 \%)$, Warsaw $(4.56 \%)$ during the study period increased to less than $10 \%$, respectively. This situation is due to factors such as the geographical location and the status of these cities, the proximity of these countries to the developed countries of the EU and less developed countries of Europe.

Each of the studied global cities is the largest city in the country for the population or the second in the ranking (St. Petersburg, Wroclaw). At the same time, the proportion of the population of these cities in the population is in the range from $1.65 \%$ (Wroclaw) to $20.87 \%$ (Minsk). Therefore, by the percentage of the global city's population in the country's population, the global cities of the East European region can be divided into 4 groups (Fig. 4):

1. Cities with a share of the population in the country more than 20\%: Minsk - 20,89\%;

2. Cities with a share of the population in the country from $20 \%$ to $10 \%$ : Sophia $-14.45 \%$, Budapest $-17.57 \%$, Prague $-12.29 \%$, Bucharest $-14.67 \%$;

3. Cities with a share of population in the country from $10 \%$ to $5 \%$ : Moscow $-8.51 \%$, Bratislava $-7.65 \%, \mathrm{Kiev}-6.92 \%$;

4. Cities with a share of the population in the country less than $5 \%$ : Warsaw $-4.55 \%$, St. Petersburg $-3.64 \%$, Wroclaw $-1.64 \%$.

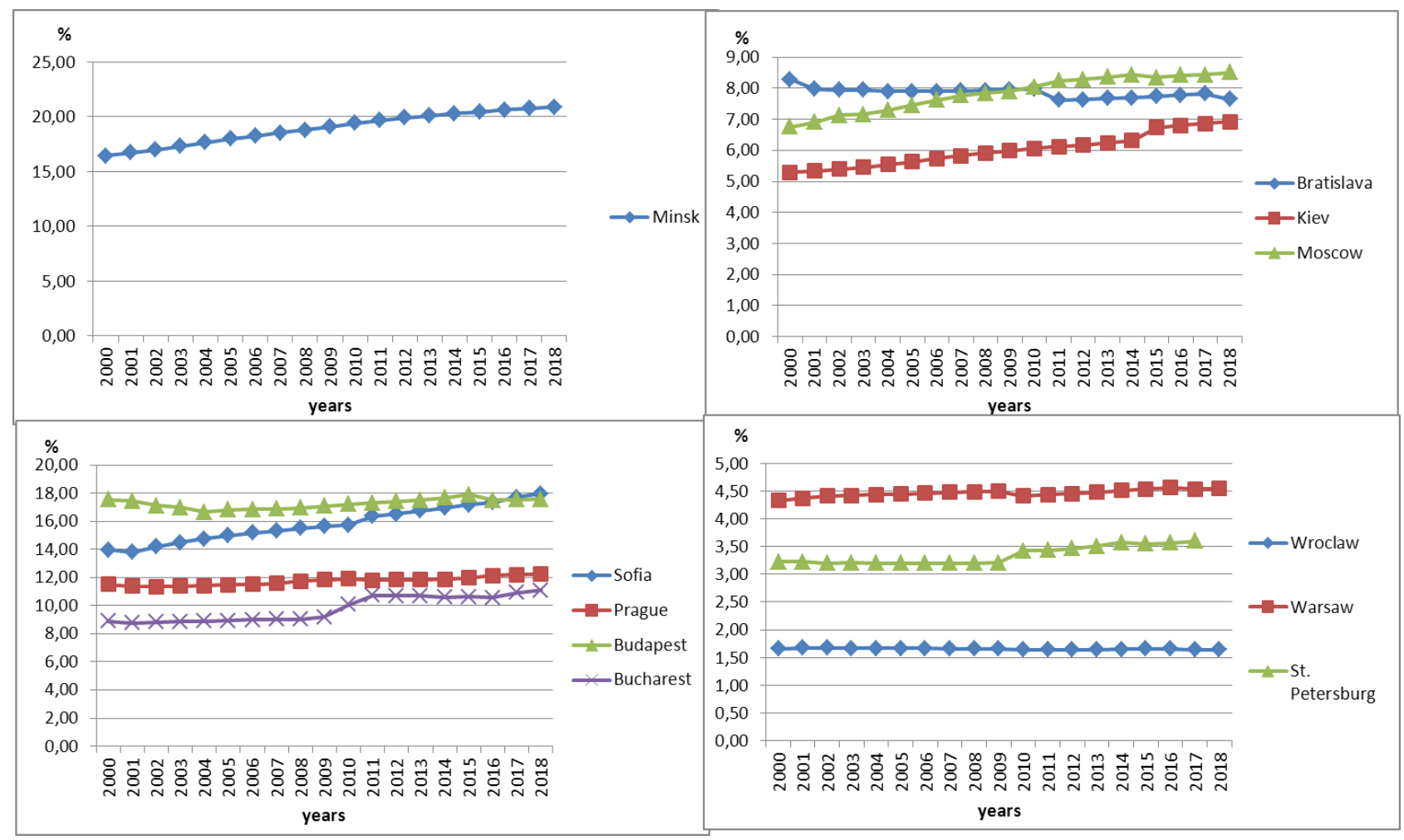

Fig. 4. Dynamics of the population share of the global cities in the East European region in the population of the countries concerned, for the period 2000-2018

(constructed by the author according to $[8-10 ; 13 ; 17-18 ; 20-24]$ )

Analyzing this distribution of cities by groups, one can conclude that Minsk is the main pole of growth in the country, pulling over $20 \%$ of the population of the country, although the urbanization rate of Belarus is more than $77 \%$. The cities of the second (Sofia, Prague, Budapest, Bucharest) and the third (Moscow, Bratislava, Kiev) groups are metropolitan cities with significant political, economic and demographic potential. At the same time, cities of the second group with a slightly larger share of the population in the country (17.57-12.29\%) are cities of mountainous countries with a rather small area.
The cities of the third group are the largest cities in the region of the studied region and their share in the population of the country in the range of 8.51$6.92 \%$. The last group includes non-metropolitan cities (St. Petersburg, Wroclaw) and the metropolitan city of Warsaw. These are cities that do not make significant demographic changes in the country, firstly, because of their non-capital situation (St. Petersburg, Wroclaw), and secondly, their location has a high level of urbanization and a large area.

For the cities of Bratislava and Wroclaw, a decrease in the share of the population in the country is 
typical for the period of the survey. For Bratislava, this is explained by the general decrease in the population of the city from 2000 to 2018 and the increase in the population of the country as a whole (from 5401 thousand in 2000 to 5447 thousand in 2018). The city of Wroclaw is also characterized by a tendency to reduction in its population (from 2000 to 2018, the city population declined by more than 9 thousand people), but a decrease in the share of the population can be explained also by an increase in the population of the capital of Poland - Warsaw by 76.39 thousand persons during the study period.

For the rest of the global cities of the Eastern European region, the share of population in the population of the countries concerned has been recorded
(Fig. 4), which in fact confirms their status as global cities.

The results of the study will allow to carry out the cluster analysis for 11 global cities in the Eastern European region and to group cities according to population dynamics and the population of the studied cities in the population of the countries concerned.

Although the countries of the region under study in the UN classification have many common features, global cities, even in terms of dynamics of the population and their share in the population, are quite different. Therefore, the global cities of the Eastern European region can be divided into 4 clusters with corset analysis (Fig. 5):

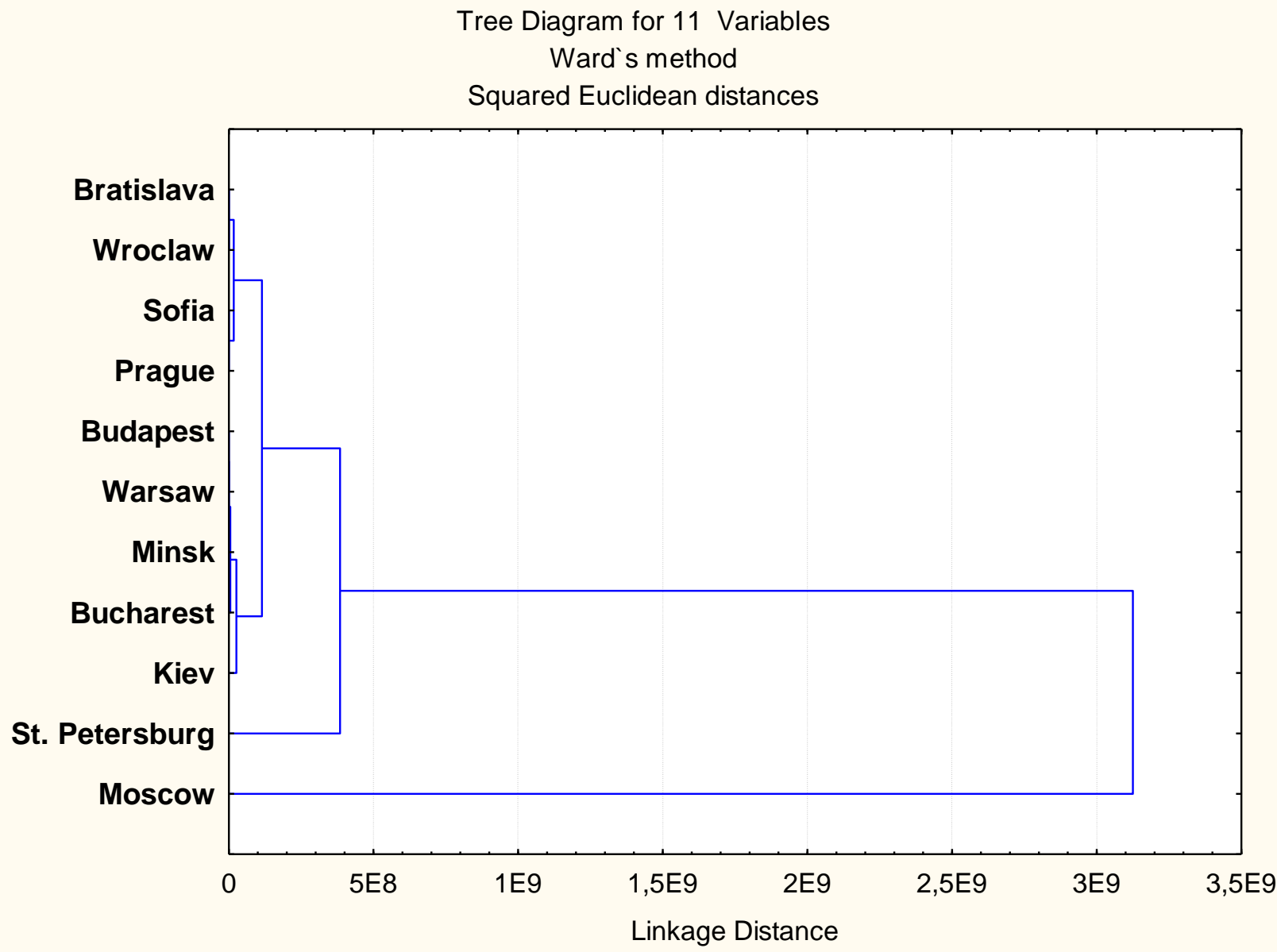

Fig. 5. Grouping of the cities of the East European region according to the dynamics of the population and their time in the population of the countries concerned for the period 2000-2018

(constructed by the author according to [11-16; 21-22; 24-25])

I. Moscow - the city with the largest population among the studied population, with a constant positive dynamics of increase and share in the population of the country more than $8.5 \%$, which is also constantly increasing;

II. St. Petersburg, Kiev - cities with a population of more than 2 million people, positive dynamics to increase population and share in the country $3.64 \%$ and $6.92 \%$, respectively. These cities have a small share in the population of the countries concerned due to the considerable development of the rest of the major cities of the countries concerned.

III. Minsk, Bucharest, Warsaw - this cluster includes cities with populations ranging from 1.5 million to 2.2 million people with a positive dynamics up to an increase in the population in the country at $20.55 \%, 11.1 \%$ and $4.55 \%$ respectively, which increases this indicator throughout the study period; 
IV. the cities of Budapest, Prague, Sofia, Wroclaw, and Bratislava are characterized by a population ranging from 440 thousand to 1.2 million, which is the smallest indicator among the global cities of the region. The cities of Sofia and Prague are characterized by an increase in the population and its share in the population of the country, and for the remaining cities, the figures are constantly decreasing over the study period.

Thus, the cities of the first and second clusters are global cities with significant demographic potential, while the pace of development for the cities under study will be characterized by further growth in the status of global. Instead, the cities of the third cluster are cities that will take measures to improve the demographic situation in order to preserve the status of global cities. For the cities of the fourth cluster, with preservation of the existing pace of demographic development their loss of the status of global cities is possible.

Conclusion. Consequently, in the global cities of the studied region, there is a fairly large proportion of the population of the country concerned. The peculiarities of the population and its dynamics in global cities greatly affect the population of the country and the region as a whole. So, one of the most important demographic indicators is the dynamics of population, so this issue requires a comprehensive study.

The conducted research on the dynamics of population size and the share of the population of the global cities of the East European region in the respective countries allowed to group the studied cities according to the indicators (Fig. 4). Analyzing the dynamics of the population, one can conclude that most of the global cities of the region are attractive for the population, which is reflected in the increase in this indicator for the period of research. Analyzing the proportion of urban population in the total population of the countries concerned, it can be argued that with the preservation of existing trends in the development of such cities as Bratislava, Wroclaw and Budapest, their global status loss is possible.

Consequently, the dynamics of the population is an important factor in the development of global cities and regions in general and directly affects their status and demographic characteristics of the rest of the territory.

1. Глазычев, В. Урбанистика / В. Глазычев // Европа. - Москва. - 2008. - 220 с.

2. Матвеева, О Ю. Глобальные города - города, меняющие сочиильно-культурное пространство / О. Ю. Матвеева // Вестник науки Сибири. - 2015. - № 1 (16). - С. 93-97.

3. Сассен, С. Глобальный город: Нью-Йорк, Лондон, Токио // C. Сассен // Princeton University Press. - 1991. $410 \mathrm{c}$.

4. Слука, Н.А. Геодемографические феномены глобальных городов / Н.А. Слука // Ойкумена. - Смоленск. 2009. - $317 c$

5. Слука, Н. А. Эволюичи концеепции «мировых городов» / Н. А. Слука// Региональные исследования. - 2005. - № 1. - C. 11-29.

6. Шпенглер, О. Закат Европьл. Очерки морфологии мировой истории. Т. 2. Всемирно-исторические перспективы: пер. с нем. и примеч. / И.И. Маханькова. - М.: Мысль, 1998. - 606 с.

7. Воронін, I. М. Формування глобальних міст як результат впливу процесів глобалізації й інформатизаџії на систему розселення [Електронний ресурс] / I. М. Воронін // Ученые записки Таврического национального университета им. В. И. Вернадского. Серия : География. - 2009. - Т. 22 (61). - № 2. - С. 167-172. - Режим docmyny: http://sn-geography. crimea.edu/arhiv/2009/uch_22_2g/020_voron.pdf

8. Головне управління статистики у м. Києві [Електронний ресурс]. - Режим доступу: http://www.kiev.ukrstat.gov.ual

9. Державна служба статистики України [Електронний ресурс]. - Режим доступу: http://www.ukrstat.gov.ua/

10. Национальный статистический комитет Республики Беларусь (Белстат) [Електронний ресурс]. - Режим docmyny : http://www.belstat.gov.by/

11. Национаольное бюро статистики республики Молдова [Електронний ресурс]. - Режим доступу : http://www.statistica.md/index.php?l=ru

12. Офіиійний сайт ООН [Електронний ресурс]. - Режим доступy: http://www.un.org/ru/index.html

13. Федеральная служба государственной статистики [Електронний ресурс]. - Режим доступу : http://www.gks.ru/

14. Sassen, S. The Global City: Introducing a Concept / S. Sassen // The Brown Journal of World Affairs. - Winter/Spring. - 2005. - Vol. XI. - Issue 2. - P. 27-43.

15. Taylor, P. The New Geography of Global Civil Society: NGOs in the World City Network // GaWC Research Bulletin. - 2004. - № 144.

16. Taylor, P. World City Network: A Global Urban Analysis / P. Taylor. - Routledge. - 2004.

17. Czech Statistical Office [Електронний ресурс]. - Режим достуny: https://www.czso.cz/csu/czso/home

18. Eurostat [Електронний ресурс]. - Режим доступу: http://ec.europa.eu/eurostat

19. Globalization and World Cities [Електронний pecypc]. - Pежим достуny: http://www.lboro.ac.uk/gawc/ courol.html 
20. Główny Urząd Statystyczny [Електронний ресурс]. - Режим достуny: https://bdl.stat.gov.pl/BDL/start

21. Hungarian Central Statistical Office [Електронний ресурс]. - Режим достуny : http://www.ksh.hu/

22. National Statistical Institute of Bulgaria [Електронний ресурc]. - Режим доступy: http://www.nsi.bg/en

23. National Statistical Institute of Romaia [Електронний ресурс]. - Режим доступy: http://www.insse.ro/cms/en

24. Statistical Office of the Republic of Slovenia [Електронний ресурс]. - Pежим доступy : http://www.stat.si/ StatWeb/en/home

25. The World According to GaWC [Електронний pecypc]. - Режим доступy : http://www.lboro.ac.uk/gawc/ gawcworlds.html

UDC 911.375:314.116(4-11)

\author{
Lyudmyla Niemets, \\ Doctor of Sciences (Geography), Professor, \\ Head of the Department of Human Geography and Regional Studies, \\ V. N.Karazin Kharkiv National University, \\ Svobody sq., 4, Kharkiv, 61022, Ukraine, \\ e-mail: soc-econom-region@ karazin.ua, https://orcid.org/0000-0001-9943-384X; \\ Olga Suptelo, \\ $\mathrm{PhD}$ student, Department of Human Geography and Regional Studies, \\ V. N.Karazin Kharkiv National University, \\ e-mail: syptelo@gmail.com, https://orcid.org/0000-0003-2901-8565 \\ Sergii Zavetnyi, \\ Doctor of Science (Philosophy), Professor, \\ Department of theoretical and practical philosophy, V. N.Karazin Kharkiv National University, \\ e-mail: kntusgunesco96@gmail.com, \\ Volodymir Redin, \\ $\mathrm{PhD}$ (Geography), Associate Professor, Department of Human Geography and Regional Studies, \\ e- mail: v.redin@gmail.com, https://orcid.org/0000-0002-1580-7662; \\ Anatoliy Baynazarov, \\ $\mathrm{PhD}$ (Geography), Associate Professor, \\ Department of Physical Geography and Cartography, V. N. Karazin Kharkiv National University, \\ e-mail: baynazarov@ukr.net
}

\title{
DYNAMICS OF THE POPULATION NUMBER IN GLOBAL CITIES OF THE EAST EUROPEAN REGION
}

Formulation of the problem. The growth of cities numbers and their population determines the urgent need to study urban demographic processes. According to the UN [2], in 2007, urban population of the world exceeded the rural population and accounted for 54\%, respectively, while the figure continues to grow. Most studies of global cities are reduced to building their hierarchical classification and studying global networks. Therefore, an increase in the proportion of urban population, in particular, population of global cities which are currently the leading centers of economic, financial, political, cultural and social development, makes the study of the demographic processes of these territories more urgent.

The purpose of the article. The purpose of this study is to analyze the population dynamics of the global cities in Eastern European region.

Results. The vast majority of studies and their corresponding publications devoted to global cities, in their essence, has a theoretical component and is the basis for the emergence of global cities concept. Despite a large number of publications, most authors emphasize the importance of the economic component in the development of world cities in their research, in relation to the demographic situation, which is considered only as one of the factors in the development of global cities.

Current political and economic situation in Europe and the fact that more than $30 \%$ of the population lives in this macro-region makes the formation of an interest in studying the countries of East European region, and, in particular, the cities.

The conducted research on the dynamics of population size and the share of the population of the global cities in East European region in the respective countries allowed us to group the studied cities according to the indicators (Fig. 5). Analyzing population dynamics, it can be concluded that most of the global cities of the region are attractive for the inhabitants, which is expressed in the increase of this indicator for the period 
of research. Analyzing the proportion of urban population in the total population of the countries, it can be argued that with the preservation of existing trends in the development of such cities as Bratislava, Wroclaw and Budapest, their loss of global status is possible.

Consequently, the dynamics of the number is an important factor in the development of global cities and regions in general, and it directly affects their status and demographic characteristics of the rest of the territory.

Keywords: global cities, East European region, the share of the city's population in the country's population, urbanization level, the growth (reduction) of the population.

1. Glasychev, B. (2008) Urbanism. Moscow, Russia: Europe, 220.

2. Matveeva, O. Ju. (2015). Global cities - cities that change the socio-cultural space. Bulletin of Science in Siberia, 1(16), 93-97.

3. Sassen, S. (1991). Global city: New York, London, Tokyo] Princeton University Press, 410

4. Sluka, N. A. (2009). Geodemograficheskiye fenomeny globalnykh gorodov [Geodemographic phenomena of global cities. Smolensk, Russia: Oecumene 317.

5. Sluka, N. A. (2005). Evolution of the Concept of World Cities. Regional Studies, 1, 11-29.

6. Spengler, O. (1998). The Decline of Europe. Essays on the morphology of world history. Vol.2. World-historical perspectives. In I. I. Makhankova (Eds.). Moscow, Russia: Mysl, 606.

7. Voronin, I. M. (2009). Formation of global cities as a result of globalization and informatization processes impact on the resettlement system. Scientific Notes of Taurida National V.I.Vernadsky University. Series: geog-raphy, 2/22(61), 167-172. Available at: http://sngeography.crimea.edu/arhiv/2009/uch_22_2g/020_voron.pdf

8. The Main Department of Statistics in Kyiv. Available at: http://www.kiev.ukrstat.gov.ual

9. State Statistics Service of Ukraine. Available at: http://www.ukrstat.gov.ual

10. National Statistics Committee of the Republic of Belarus (Belstat). Available at: http://www.belstat.gov.by/

11. National Bureau of Statistics of the Republic of Moldova. Available at: http://www.statistica.md/index.php?l=ru

12. United Nations official website. Available at: http://www.un.org/ru/index.html

13. Federal State Statistics Service. Available at: http://www.gks.ru/

14. Sassen, S. (2005). The Global City: Introducing a Concept. The Brown Journal of World Affairs, Winter / Spring, 9(2), 27-43.

15. Taylor, P. The New Geography of Global Civil Society: NGOs in the World City Network. GaWC Research Bulletin, 144.

16. Taylor, P. (2004). World City Network: A Global Urban Analysis. Routledge, 256

17. Czech Statistical Office. Available at: https://www.czso.cz/csu/czso/home

18. Eurostat. Available at: http://ec.europa.eu/eurostat

19. Globalization and World Cities. Available at: http://www.lboro.ac.uk/gawc/courol.html

20. Gtówny Urząd Statystyczny. Available at: https://bdl.stat.gov.pl/BDL/start

21. Hungarian Central Statistical Officem. Available at: http://www.ksh.hu/

22. National Statistical Institute of Bulgaria. Available at: http://www.nsi.bg/en

23. National Statistical Institute of Romania. Available at: http://www.insse.ro/cms/en

24. Statistical Office of the Republic of Slovenia. Available at: http://www.stat.si/StatWeb/en/home

25. The World According to GaWC. Available at: http://www.lboro.ac.uk/gawc/gawcworlds.html 